\title{
Students' Attitudes towards Acoustics and its Impact on Academic Achievement
}

\author{
Ahmed Obralić MA \\ KenanaDemirovića 5, Sarajevo \\ Email: ahmedobralic@hotmail.com
}

Doi:10.5296/ ijld.v6i1.8957ＵRL: http://dx.doi.org/10.5296/ ijld.v6i1.8957

\begin{abstract}
The aim of the study was to investigate the students' perception of the acoustics in terms of academic achievement, high educational buildings from different periods of time, and gender. The quantitative research was conducted among 208 students at higher educational institutions from different historical periods in Bosnia and Herzegovina. The quantitative method was used in order to get desired data. The questionnaire was based on previous studies and examined literature. We found out significant correlation between students' academic achievement and the acoustics. Besides, the results indicated significant difference between high educational buildings from different periods of time in terms of the acoustics. What's more, the difference was significant in terms of gender. We believe this study has provided some interesting and valuable information and implications that can be involved in the increasing of students' performance at the universities in Bosnia and Herzegovina, which will contribute to the improvement in education system of Bosnia in general.
\end{abstract}

Keywords: Physical environmental factors, performance, students' comfort, acoustics

\section{Introduction}

The purpose of this paper is to examine one of the relevant factors that is considered as determining factor of comfort in interior space, the acoustics. Besides, we examined the correlation of human comfort with productivity, as well as the influence of the factors on students' achievement and performance. We intended to show students' attitudes towards the educational ambience and examine to what extends acoustics affect human comfort, in order to improve the high educational institutions in Bosnia and Herzegovina. In terms of human comfort, Hadrovic (1996) points out that several parameters are important for analysis: the temperature of inner space, the temperature of inner area of wall surfaces, the vertical gradient of air temperature, the humidity of indoor air, the velocity of air flow, the air composition (the presence of carbon dioxide, oxygen, odors, gases etc.), the lightening, and the acoustics. Thus, our focus was the acoustics. 


\section{BACKGROUND OF THE STUDY}

The architectural design represents complex and very useful scientific area in which every entry offers numerous opportunities for research. Many researchers tried to find the answer to the questions about the most proper learning environment which will provide the best environment for students' productivity. Dealing with architecture and creating the living and working area is not just a mere designing and making drawings. Architecture is a wide science that includes many disciplines that should be reached in order to get good results. The architect cannot be a psychologist, a doctor, an anthropologist a philosopher and an esthetician at the same time, but s/he needs to be involved enough in each field from where s/he can take answers on questions during design (Hadrovic, 1996). Regarding the physical environment on the behavior of a man, Prochansky (1975) pointed: "The physical environment refers to the complexity that constitutes any physical setting in which men live, interact, and engage in activities for either brief or extended periods. It is the system of instrumental objects and life-supporting conditions organized in space and time to support and mediate the behavior and experience of the individual alone and in relation to other individuals" (p. 16). Due to the fact that environment shapes our lives, Skinner (1953) states that environments should not be observed as a place where the human gets born, reproduce and die. He stands that environment always impacts the human life in every sphere of its part. According to the famous environmental psychologist, Judith H. Heerwagen (2003), many factors, such as exposure to nature and daylight, air quality, temperature, odors, noise, ergonomics, and opportunities for social gathering, relaxation, and exercise, affect occupants' performance and well-being.

In terms of educational institutions, plenty of research is conducted in that sense, focused on developing of teaching process and not giving a big importance to the ambience in which the teaching process is being held. Even though the human being is affected by his/her environments, fulfillments of requirements within school building are mostly observed from the social rather than physical perspective. Sometimes physical elements are forgotten while schools are built. Today, authorities with all their forces struggle to create positive learning achievement, or even to improve it. In most cases, students are given extra tests and exposed to the extra curriculum activities. However, less attention is paid to the learning environment. Physical environment is very important and school environment really need to consider a building-based change.

Meanwhile, Castaldi (1977) states that the examination of the environment where educational process was occurring, was in second plan, without enough attention paid to this field. The importance and need of students to learn in a comfort learning environment is crucial and needs to be examined and studied. Some of the students can achieve no matter of circumstances where the learning process occur, they are fully motivated, willing to learn more. This stands for particular cases and cannot be observed in general, but we should work on improvement of learning environment, because the major number of students prefers comfort and challenging environment. 


\section{LITERATURE REVIEW:}

Researchers confirmed the correlation between the performance of the students and the quality of acoustics in the classrooms. Siebein, Gold, Siebein and Ermann (2000) explain that classroom success requires a high-quality design, a holistic planning and other construction processes where the physical size and layout of the classroom is not so much important as well as material and equipment selection. To prove that acoustics should be taken in consideration in very beginning of design process, Z. Karabiber and E. Celik made the research (2001) on cost analysis of improvement of already existing classrooms. They made evaluation of current acoustical conditions in some classrooms in Turkey, and gave a cost calculation of improvement. Having the relatively big digits in sum, they concluded that it is better to pay more attention on acoustical requirements during design.

Maffei, Iannace and Masullo dealing with acoustics in historical buildings in 2008, stated that the classrooms inside of historical buildings in sense of reverberation and acoustics are very poor. The reason is the large volume and the absence of absorbing materials. Regarding the absorbing materials, the work of Dodd, Wilson, Valentine, Halstead and McGunnigle from 2003, showed that ceiling absorption and a resulting low reverberation time significantly affects the design of a classroom in sense of acoustical performance. Since the absorbing materials are in correlation with sound reverberation, Astolfi, Perino and Piccaluga (2003) worked on how to find the optimum reverberation time that will provide good speech intelligibility, and they also tried to reach the best location for the materials that will absorb the sound in classrooms. While investigating how to improve the speech intelligibility in university classrooms, they got the result that the poor acoustics of the classroom can have huge impact on a health of lecturers as well. Larsen, Vega and Ribera (2008) examining the effect of acoustics on word recognition, stated that the amplification of the sound-field system is beneficial for word recognition and the hearing in general.

Besides absorbing materials, the shape and position of the classroom influence the quality of acoustics in teaching environment. Regarding that, Bondi, Picininni and Stefanizzi (2001) in examining the acoustics in rectangular classrooms, stated that if the length of a classroom is doubled, the intelligibility is reduced and the reverberation is increased.

Based on their study, Baker and Bernstein (2012), claim that the students' achievement has negative influenced by the inside and outside noise. Sutherland and Lubman in their work in 2002, tried to define impact of acoustical noise or reverberation on scholastic performance by considering aircraft noise, ground transportation noise, the noise of heating, ventilating and air conditioning. They found that there is correlation between scholastic achievement and acoustics. They also gave some recommendations for decision makers how to improve acoustics in the school environment, especially where language skills are taught. Dealing also with noise, Jeffery and Shield in they work (2002) measured the noise coming from outside in 142 and the noise coming from inside of the school in 16 schools. They claimed that the acoustic inside of the classroom of primary schools is determined by inside noise more than the noise coming from outside such as road traffic, factories etc. On the contrary, Dockrell, 
Tachmatzidis, Shield and Jeffery (2003) by examining students in different classroom conditions claim that most of the students were more annoyed by external noise and students were aware of acoustics in general.

Examining the categories affected by noise, Shield and Dockrell (2003), stated that the influence of noise varies according to the age of the students, he also states that the students are annoyed in different values. Besides, Lukas (2002) upon his investigations has the attitude that outdoor noise influences more the non-English-fluent students, more than English fluent students. Also Nelson, Kohnert, Sabur and Shaw (2005) made research on ESL (English as a second language) students and concluded that the negative impact of noise on them is bigger than the noise impact on English native speakers. The negative affected category can also be a teacher, so in study by Enmarker and Boman (2004), the result showed that impact of the noise was bigger on teachers than students. The negative impact reflected as high blood pressure and tiredness. The affected categories are more teachers, increasing their voice in order to be heard. Meanwhile, it can cause a stress and fatigue (Tiesler \& Oberdoster, 2008)

Klatte et al, (2011) studied the classroom reverberation and the students' comfort and well-being in Denmark. They tried to focus on the speech abilities, short-term memory and motivation in different classrooms within different reverberation times. As the reverberation time was high, the negative impact on speech abilities and motivation was high respectively.

\section{THEORETICAL FRAMEWORK:}

According to a famous environmental psychologist, Dr. Judith H. Heerwagen (2003), many factors, such as exposure to nature and daylight, air quality, temperature, odors, noise, ergonomics, and opportunities for social gathering, relaxation, and exercise, affect occupants' performance and well-being. While defining the factors which directly influence the students' performance, Earthman (2004) states that Acoustical Control has an essential role. Besides, the acoustics include elements such as: noise, reverberation, signal to noise ratio.

\section{METHODOLOGY:}

In order to gain desired data, it was necessary to design a questionnaire that will offer answers to research questions. It is decided on creating a survey as the most appropriate research design for the investigation of the issues of interest. For this reason, the survey method is used that stands for structuring questions to assess people's beliefs, attitudes, and self-reports of behavior. Survey also provided information for correlation research. Some responses to the questions were correlated (often demographic questions) with responses to other questions (often attitudes or reports of behavior). Survey questions are composed clearly and unambiguously. It was written and delivered in hard copy and soft copy via emails. 


\section{OBJECTIVES OF THE STUDY}

2016, Vol. 6, No. 1

The aim of the study was to investigate the students' perception of the acoustics in terms of academic achievement, high educational buildings from different periods of time, and gender.

\section{RESEARCH QUESTIONS}

The research questions investigated the correlation between the acoustics and students' academic achievement; difference between high educational buildings from different periods of time in terms of the acoustics; and difference between male and female perception of acoustics.

\section{PARTICIPANTS}

Subjects for the study included $208(\mathrm{~N}=208)$ students (male, $\mathrm{N}=67 \&$ female, $\mathrm{N}=141)$ from five faculties from three historical periods: Austro-Hungarian Empire (Faculty of Law and Faculty of Islamic Studies, University of Sarajevo, Sarajevo), Socialist period (Faculty of Philosophy and Faculty of Political Science, University of Sarajevo, Sarajevo) and After-war period (Faculty of Economics, International Burch Faculty, Sarajevo and Faculty of Architecture, International Burch Faculty, Sarajevo).

\section{INSTRUMENTATION AND DATA ANALYSIS}

The quantitative method was used in order to get desired data. The questionnaire was based on previous studies and examined literature. The validity and reliability of questionnaire was confirmed. It was comprised of 20 statements, with a rating scale from one to five for each one of them, Likert scale. The pilot study was conducted right after. The responses of the students were analyzed using Statistical Package for the Social Sciences (SPSS) version 21 to obtain the results.

\section{RESEARCH FINDINGS}

The results indicated that there is a strong correlation (Person $r=-143^{*}$ )between students' academic achievement (GPA) and the acousticsat the 0.05 level (2-tailed)at faculties from three different historical periods in Bosnia and Herzegovina. Results also indicated significant difference, where the value of .000 ( $\mathrm{Sig}=0.000)$ between high educational buildings from different periods of time in terms of the acoustics. Female and male participants perceived acoustics differently. The observed Sig. value of Levene's test for acoustic is .139 ( $\mathrm{Sig}=0.555)$ since it is larger than .05, the first line of the table is observed (Equal variances assumed). Under the section labeled as t-test for equality of means (M), the column labeled Sig. (2-tailed), shows the value of $\mathrm{Sig}=$. 009. It means there was significant difference between the female and male respondents in the research in terms of acoustics 
We found out that in terms of acoustics, the students are most pleased at institutions from After-war period ( $M=16.00)$, Socialist period $(M=13.43)$, and Period of Austro-Hungarian Empire ( $M=13.42)$. It implies that acoustics in faculty buildings constructed in recent history are perceived better than these buildings from Austro-Hungarian period and from period of Socialism. There is no significant difference between Period of Austro-Hungarian Empire and Socialist period. The significant difference was noticed in students' attitudes towards acoustics from institutions constructed in After-war period. It implies that acoustics at institutions from the After-war period( $M=16.00)$ is much better than in the institutions from the Socialist period $(M=13.43)$ and Period of Austro-Hungarian Empire $(M=13.42)$. This result confirms the claims on the acoustics in historic buildings by Maffei, Iannace and Masullo (2008), when they state that historical buildings are poor in regard to acoustics and reverberation. As a reason, they see volume of the rooms and the absence of absorbing materials. The institutions from the Period of Austro-Hungarian Empire, built in neo-renaissance have high ceilings and big volume. Terrazzo floor was also used in that time. Siebein, Gold, Siebein and Ermann (2000) claim that classroom needs to be high-quality designed and that design requires a holistic approach. They also claim that materials and equipment selection are important factors in classroom acoustics.

Investigating the means within two groups, the test showed that male students $(M=14.72)$ are more pleased with acoustics rather than female $(M=13.54)$ students.

\section{CONCLUSION}

The intention of the study was to examine and discuss the physical environmental factor / the acoustics within the context of human comfort that impact the academic achievement of the students. The investigation was done in high educational institutions where lectures are held in buildings from three different periods of $20^{\text {th }}$ and $21^{\text {th }}$ century in Bosnia and Herzegovina. Special attention during design process must be paid to educational institutions. This is due to the fact that students are sensitive category of space users, and on the other hand, the space of school is occupied with high density of humans in comparison with residential and office buildings. The students showed different attitudes towards physical environmental factor / the acoustics in different environments. The students are generally less satisfied with environmental conditions in buildings from Austro-Hungarian and period of Socialism, where they also agree about the need of renovation of these faculties. The students of faculties built in post-war period are more pleased with building condition in terms of the acoustics, despite the lack of mechanical ventilation, contemporary daylight diffusers, glare protectors etc. Can renovated buildings from Austro-Hungarian and Socialist period be compared with buildings from recent history? If the same effect cannot be reached, then the efforts on improvement of space must be the topic to analyze. In terms of acoustics, the renovation should refer to putting different kinds of materials in use. Changing flooring material, covering walls with different materials or placing the sound absorbers in classrooms might be some of solution for bad acoustics. 
For the future studies, certainly, there are some more opportunities to extend the theoretical framework in order to make further investigations on this topic. The further investigation, besides physical, could include the psychological factors in order to extend the research. Also possible extends in research could be made by going out from the classroom, researching all facilities included in educational building, even including these facilities in building's surrounding, such as access ways, approaching stairs, faculty garden etc.

This study has provided some interesting and valuable information and implications that can be involved in the increasing of students' performance at the universities in Bosnia and Herzegovina, which will contribute to the improvement in education system of Bosnia in general.

\section{REFERENCES:}

Astolfi, Perino and Piccaluga (2001).A Procedure to Improve Speech Intelligibility in University Classrooms. In $17^{\text {th }}$ International Congress on Acoustics; Proc. Int. conf., Rome, 2-7, Septembar

Baker, L. (2010). What school buildings can teach us: post-occupancy evaluation surveys in K-12 learning environments.Masters Thesis, Department of Architecture, University of California at Berkeley, Berkeley, CA.

Baker, L. (2011). A History of School Design and its Indoor Environmental Standards, 1900 to Today. Washington, DC: National Clearinghouse for Educational Facilities. www.ncef.org

Baker, L., \& Bernstein, H. (2012). The Impact of School Buildings on Student Health and

Castaldi (1977) Castaldi, B. Educational facilities: planning, remodelling, and management. Boston, Massachusetts: Allyn and Bacon, Inc., 1977

Castaldi, B. (1969). Creative Planning of Educational Facilities.Chicago, IL: Rand McNally \& Co.

Dockrell JE, Shield BM (2006). Acoustical barriers in classrooms: the impact of noise on performance in the classroom. Brit

Dockrell, Tachmatzidis, Shield and Jeffery (2003) Dockrell, J.E. and Shield, B.M. (2003) Childrenís perception of their acoustic doctoral dissertation, University of Iowa, 1966.

Dodd G, Wilson O, Valentine J, Halstead M, McGunnigle K (2001), "Classroom Acoustics a New Zealand Perspective", paper presented at the 17th International Congress on Acoustics

Enmarker and Boman (2004), Enmarker, I., \&Boman, E., \&Hygge, S. (2004). The effects of noise on word fluency environment at home and at school. Submitted for publication in Journal

Hadrovic, A.(1996). Arhitektonskafizika, StudentskastamparijaUniverziteta, Sarajevo 
Heerwagen, J. H., \&Orians, G. H. (1986). Adaptations to Windowlessness: A Study of the Use of Visual Decor in Windowed and Windowless Offices. Environment and Behavior, 18(5), 623-639.)

Karabiber\&E. Celik (2001). Estimated Cost for Improving Acoustical Comfort Conditions of an Existing Classroom, Classroom Acoustics, Sessions, YildizTeknikUniversitesi.

Klatte, M., Hellbruck, J., Seidel, J., Leistner, P. (2010). Effects of classroom acoustics on performance and well-being in elementary school children: A field study. Environment and Behavior, 42, 5, 659-692.

Larsen, Vega and Ribera (2008) Research and Technology 'The Effect of Room Acoustics and Sound- Field Amplification on Word Recognition Performance in Young Adult Listeners in Suboptimal Listening Conditions, Research and Technology

Lukas J.S. (2002) Noise, Classroom Behavior and Third and Sixth Grade Reading Achievement, Consultants in Engineering Acoustics

Maffei, Iannace and Masullo (2008). Are classrooms in historical buildings compatible with good management. Boston, Massachusetts: Allyn and Bacon, Inc., 1977.

Nelson, P., Kohnert, K., Sabur, S., \& Shaw, D. (2005). Classroom noise and children learning through a second language: Double jeopardy? Language, Speech, and Hearing Services in Schools, 36, 219-229

Proshansky, H.M. (1975). Proshansky, H. M. Theoretical issues in environmental psychology.Psychology, Beijing, 8-14 Aug 2004

Shield B.M. and Jeffery R.L. (2002) School of Engineering Systems and Design, South Bank University, London SE1 OAA, UK

Siebein, Gold, Siebein and Ermann (2000).Ten ways to provide a high-quality acoustical environment in schools. Language, Speech, and Hearing Services in Schools, v31 n4 p376-84

Skinner, B. F. (1953) Science and human behavior. New York: The MacMillan Co.

Sutherland, L. and Lubman, D. (2002), Role of Soundscape in Children's learning, Proceedings of First Pan/American/Iberian Meeting on Acoustics, Cancun, Mexico

Tiesler\&Oberdörster, 2008.Tiesler, T., \&Oberdörster, O. (2008). Noise - A stressor? Acoustic ergonomics of schools.Building Acoustics, 15(3), 249-262. 